\title{
Molecular hydrogen in mantle minerals
}

\section{Yang ${ }^{1 *}$, H. Keppler ${ }^{2 *}$, Y. Li $^{1}$}

\section{Abstract}

Current models assume that hydrogen was delivered to Earth already in oxidised form as water or $\mathrm{OH}$ groups in minerals; similarly, it is generally believed that hydrogen is stored in the present mantle mostly as $\mathrm{OH}$. Here we show by experiments at $2-7 \mathrm{GPa}$ and $1100-1300{ }^{\circ} \mathrm{C}$ that, under reducing conditions, molecular hydrogen $\left(\mathrm{H}_{2}\right)$ has an appreciable solubility in various upper mantle minerals. This observation suggests that during the accretion of the Farth, nebular $\mathrm{H}_{2}$ could have been delivered to the growing solid planet by direct dissolution in a mare f liss a of dissed contain almost no $\mathrm{OH}$ groups.

Received 13 March 2016 | Accepted 5 May 2016 | Published 18 May 2016

\section{Introduction}

The presence of hydrogen in the silicate mantle is a key parameter in influencing Earth's climate, habitability, and geochemical evolution; without some hydrogen in the mantle, plate tectonics would likely not exist on Earth (Regenauer-Lieb et al., 2001; Mierdel et al., 2007). The formation of OH defects in nominally anhydrous minerals (Bell and Rossman, 1992; Keppler and Smyth, 2006) requires a sufficiently high oxygen fugacity, $f_{2}$, to oxidise hydrogen to molecular $\mathrm{H}_{2} \mathrm{O}$ or $\mathrm{OH}$ groups. However, highly reducing conditions may prevail deep in the modern Earth (Frost and McCammon, 2008), as well as on the Moon and on Mars (Wadhwa, 2008). The early Earth (Yang et al., 2014), especially during its early accretion (Rubie et al., 2011), was likely extremely reduced, with $\mathrm{fO}_{2}$ far below the Fe-FeO buffer. Under these conditions, hydrogen is not oxidised to $\mathrm{H}_{2} \mathrm{O}$, but is present as $\mathrm{H}_{2}$, and the retention of $\mathrm{H}$ in the early mantle would then

. State Key Laboratory for Mineral Deposits Research, School of Earth Sciences and Engineering, Nanjing University, Nanjing 210023, China

Corresponding authors (email: xzyang@nju.edu.cn; hans.keppler@uni-bayreuth.de)

2. Bayerisches Geoinstitut, Universität Bayreuth, 95440 Bayreuth, Germany

only be possible if $\mathrm{H}_{2}$ could be directly dissolved in mantle minerals. This doe not appear implausible from available data on He solubility in olivine (Parman et al., 2005). In this study, we have investigated the solubility of $\mathrm{H}_{2}$ in olivine, orthopyroxene (opx), clinopyroxene (cpx) and garnet by experiments at 2-7 GPa $1100-1300{ }^{\circ} \mathrm{C}$ and $\mathrm{Fe}-\mathrm{FeO}$ buffered conditions. Experiments were conducted on gem-quality single crystals, and recovered large crystals (up to 2-3 mm in size) were studied by Fourier-transform infrared (FTIR) spectroscopy (see Supplementary Information).

\section{$\mathrm{H}_{2}$ Dissolution and Quantification}

Details of the experiments are given in Table 1, and representative spectra are illustrated in Figures 1 and 2. A small peak at $\sim 4062 \mathrm{~cm}^{-1}$ was observed for most of the annealed crystals. This peak cannot be caused by gaseous $\mathrm{H}_{2}, e . g$, in fluid inclusions, because $\mathrm{H}_{2}$ does not possess a dipole moment and therefore is not infrared active. Also, this peak cannot be attributed to overtones of $\mathrm{OH}$ or of any other species, because in an experiment at $2.5 \mathrm{GPa}$ and $1250{ }^{\circ} \mathrm{C}$ buffered by $\mathrm{Fe}_{2} \mathrm{O}_{3}-\mathrm{Fe}_{3} \mathrm{O}_{4}$ (with $f_{2}$ about 9 log units above the $\mathrm{Fe}-\mathrm{FeO}$ buffer), yielding very oxidising conditions where $\mathrm{H}_{2}$ in the system is negligible, the annealed thick opx crystal showed strong $\mathrm{OH}$ bands, but no band in the $4100-4000 \mathrm{~cm}^{-1}$ range (Fig. S-2). We also show that this peak is unrelated to the embedding medium used during sample polishing (Fig. S-3). The only plausible explanation for the peak is therefore that it is due to $\mathrm{H}_{2}$ dissolved in the lattice of the crystals.

Polarised FTIR determinations on an opx sample along the $a, b$ and $c$ axes show that the absorption of $\mathrm{H}_{2}$ is anisotropic, with stronger absorbance along $a$ and $c$ than along $b$ axes (Fig. 1). This confirms that $\mathrm{H}_{2}$ is actually physically dissolved in the crystal lattice. It is known from previous studies on glasses that the interaction with the surrounding silicate matrix can produce an induced dipole in the $\mathrm{H}_{2}$ molecule, which makes it slightly infrared active (Shelby, 1994; Schmidt and Holtz, 1998. Hirschmann et al 2012). The $\mathrm{H}_{2}$ frequency observed in this study is lower than in silicate glasses by $30-70 \mathrm{~cm}^{-1}\left(4105-4140 \mathrm{~cm}^{-1}\right)$, which in turn is $\sim 50 \mathrm{~cm}^{-1}$ lower than in vapour (Shelby, 1994; Schmidt and Holtz, 1998; Hirschmann et al., 2012). The peak of $\mathrm{H}_{2}$ in olivine is not obvious at 2.5 GPa and $1250^{\circ} \mathrm{C}$, unlike for opx, cpx and garnet, but is markedly enhanced at $7 \mathrm{GPa}$ and $1300{ }^{\circ} \mathrm{C}$ (Fig. 2). This suggests a profound role of pressure on $\mathrm{H}_{2}$ dissolution in silicate minerals, similar to that observed for silicate glasses (Hirschmann et al., 2012). For the same annealed cpx or garnet sample, the intensity of the $\mathrm{H}_{2}$ peak, i.e. either the linear or integral absorbance, decreases with crystal thickness upon further polishing (Table 1 and Fig. 2c-d), as expected by the Beer-Lambert Law. However, the garnet sample shows much stronger absorbance at a greater thickness, which may be due to a zoned H distribution in the crystal or some loss of $\mathrm{H}_{2}$ during the polishing process. 
Table 1 Details of $\mathrm{H}_{2}$ dissolution experiments.

\begin{tabular}{|c|c|c|c|c|c|c|c|c|c|c|c|}
\hline Sample & $\begin{array}{c}P \\
(\mathrm{GPa})\end{array}$ & $T\left({ }^{\circ} \mathrm{C}\right)$ & $\begin{array}{c}\mathrm{fO}_{2} \\
\text { buffer }\end{array}$ & $\begin{array}{c}f \mathrm{H}_{2} \\
\text { (bar) }\end{array}$ & $\begin{array}{c}\text { Dura- } \\
\text { tion } \\
(\mathrm{hr})\end{array}$ & $\begin{array}{c}\text { Thick- } \\
\text { ness } \\
(\mathrm{mm})^{\mathrm{a}}\end{array}$ & $\begin{array}{c}\text { Area } \\
\left(\mathrm{cm}^{-2}\right)\end{array}$ & $\begin{array}{l}\text { Height } \\
\left(\mathrm{cm}^{-1}\right)\end{array}$ & $\begin{array}{c}\text { ppm } \\
\mathrm{H}_{2} \mathrm{O}^{\mathrm{b}}\end{array}$ & $\begin{array}{l}\text { ppm } \\
\mathrm{H}_{2} \mathrm{O}^{\mathrm{c}}\end{array}$ & $\begin{array}{l}\text { wt. \% } \\
\mathrm{H}_{2} \mathrm{O}^{\mathrm{d}}\end{array}$ \\
\hline \multicolumn{12}{|c|}{ unpolarised FTIR } \\
\hline opx & 2 & 1100 & $\mathrm{Fe}-\mathrm{FeO}$ & $5.45 \mathrm{E}+4$ & 24 & 2.27 & 2.58 & 0.065 & 15 & 14 & 0.137 \\
\hline opx & 2.5 & 1250 & $\mathrm{Fe}-\mathrm{FeO}$ & $8.25 \mathrm{E}+4$ & 24 & 1.42 & 3.11 & 0.079 & 18 & 17 & 0.167 \\
\hline opx & 2.5 & 1250 & $\begin{array}{l}\mathrm{Fe}_{2} \mathrm{O}_{3-} \\
\mathrm{Fe}_{3} \mathrm{O}_{4}\end{array}$ & $4.68 \mathrm{E}+0$ & 24 & 1.31 & 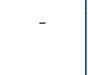 & - & - & . & - \\
\hline olivine & 2.5 & 1250 & $\mathrm{Fe}-\mathrm{FeO}$ & $8.25 \mathrm{E}+4$ & 24 & 1.99 & - & - & - & - & - \\
\hline olivine & 7 & 1300 & $\mathrm{Fe}-\mathrm{FeO}$ & $3.02 \mathrm{E}+6$ & 16 & 1.72 & 2.95 & 0.077 & 17 & 16 & 0.161 \\
\hline garnet & 2.5 & 1250 & $\mathrm{Fe}-\mathrm{FeO}$ & $8.25 \mathrm{E}+4$ & 24 & 2.46 & 3.51 & 0.131 & 20 & 27 & 0.275 \\
\hline garnet & 2.5 & 1250 & $\mathrm{Fe}-\mathrm{FeO}$ & $8.25 \mathrm{E}+4$ & 24 & 2.94 & 6.34 & 0.232 & 37 & 48 & 0.486 \\
\hline cpx & 2.5 & 1250 & $\mathrm{Fe}-\mathrm{FeO}$ & $8.25 \mathrm{E}+4$ & 24 & 1.41 & 4.52 & 0.128 & 26 & 27 & 0.268 \\
\hline cpx & 2.5 & 1250 & $\mathrm{Fe}-\mathrm{FeO}$ & $8.25 \mathrm{E}+4$ & 24 & 2.49 & 4.66 & 0.149 & 27 & 31 & 0.313 \\
\hline
\end{tabular}

\section{polarised FTIR}

\begin{tabular}{|l|c|c|c|c|c|c|c|c|c|c|c|}
\hline opx E//a & 2 & 1100 & Fe-FeO & $5.45 \mathrm{E}+4$ & 24 & 2.27 & 2.78 & 0.079 & 5 & 6 & 0.056 \\
opx E//b & 2 & 1100 & Fe-FeO & $5.45 \mathrm{E}+4$ & 24 & 2.06 & 1.41 & 0.047 & 3 & 3 & 0.033 \\
opx E//c & 2 & 1100 & Fe-FeO & $5.45 \mathrm{E}+4$ & 24 & 2.27 & 3.53 & 0.089 & 7 & 6 & 0.062 \\
\hline total & & & & & & & 7.72 & 0.215 & 15 & 15 & 0.151 \\
\hline
\end{tabular}

To facilitate comparison, all $\mathrm{H}_{2}$ contents are given as the equivalent contents of $\mathrm{H}_{2} \mathrm{O}$. Height and area are the linear and integral absorbance of the $\sim 4062 \mathrm{~cm}^{-1}$ peak, respectively normalised to $1 \mathrm{~cm}$ thickness. Unpolarised and polarised data of opx annealed at $2 \mathrm{GPa}$ and $1100^{\circ} \mathrm{C}$ are for the same sample from the $1^{\mathrm{st}} \mathrm{stage} \mathrm{H}_{2}$ dissolution run (see Supplementary Information). Data labelled total are the sum along $a, b$ and $c$ axes. For the opx crystal, the absorbance of unpolarised analysis is about $1 / 3$ the total absorbance of polarised analyses, probably due to the orientation effect. $\mathrm{H}_{2}$ is the calculated equilibrium $\mathrm{H}_{2}$ fugacity (see details in Yang, 2016).

- The peak is too weak for any quantitative evaluation (see Fig. 2a).

.

${ }^{b}$ Estimated by the integrated area of the $\sim 4062 \mathrm{~cm}^{-1}$ peak with the determined extinction coefficient of 4.63 $\mathrm{ppm}^{-1} \mathrm{H}_{2} \mathrm{O} \mathrm{cm}^{-2}$ for opx

of the $\sim 4062 \mathrm{~cm}^{-1}$ peak with the determined extinction coefficient of $0.13 \mathrm{ppm}^{-1} \mathrm{H}_{2} \mathrm{O} \mathrm{cm}$ for opx.

Estimated by the reported extinction coefficient of $0.26 \mathrm{~L} / \mathrm{mol} \mathrm{cm}$ for $\mathrm{SiO}_{2}$ glass by Shelby (1994).

Quantification of $\mathrm{H}_{2}$ in these samples is not easy; methods such as ion microprobe (SIMS) are unsuitable, as SIMS can only measure the total $\mathrm{H}$ content, including the contribution from $\mathrm{OH}$. To quantify $\mathrm{H}_{2}$, we therefore carried out twostage annealing experiments on an opx crystal (see Supplementary Information). The crystal was first annealed in $\mathrm{H}_{2}$ and then re-annealed at high $\mathrm{fO}_{2}$ to convert the dissolved $\mathrm{H}_{2}$ into $\mathrm{OH}$; the increased $\mathrm{OH}$ absorbance was measured by FTIR and converted into water contents. Blank experiments confirmed the reliability of the method. This yields absorption coefficients for polarised FTIR measurements of $\mathrm{H}_{2}$ in opx of $\sim 4.63 \mathrm{ppm}^{-1} \mathrm{H}_{2} \mathrm{O} \mathrm{cm}^{-2}$ for the integral intensity and of $\sim 0.13 \mathrm{ppm}^{-1}$ $\mathrm{H}_{2} \mathrm{O} \mathrm{cm}-1$ for the linear intensity, where the concentration of dissolved $\mathrm{H}_{2}$ is expressed as the equivalent form of $\mathrm{H}_{2} \mathrm{O}$. By applying these values together with an orientation factor of $1 / 3$ to the unpolarised spectra, $\mathrm{H}_{2}$ contents in the samples can be estimated. The use of the same extinction coefficient for different minerals is justified, since the position and shape of the $\mathrm{H}_{2}$ band is virtually the same. Observed hydrogen contents are mostly $\sim 15-40 \mathrm{ppm} \mathrm{H}_{2} \mathrm{O}$. The data for olivine clearly show that hydrogen solubility increases with pressure, as expected from the increase of hydrogen fugacity. Moreover, the hydrogen contents given in Table 1 should be considered as minimum values. This is because the hydrogen contents are so small that it is conceivable that in the two-stage calibration runs, not all the $\mathrm{H}_{2} \mathrm{O}$ produced by oxidation of $\mathrm{H}_{2}$ was re-dissolved in the crystal; some may remain adsorbed on the surface. This could lead to some systematic underestimation of hydrogen solubility. Only for reference, Table 1 also contains hydrogen contents calculated using the linear calibration coefficient for $\mathrm{H}_{2}$ in $\mathrm{SiO}_{2}$ glass (Shelby, 1994). This would yield numbers higher by a factor of $\sim 100$ However, the position of the $\mathrm{H}_{2}$ peak differs between $\mathrm{SiO}_{2}$ glass and minerals, and accordingly, the extinction coefficient is likely also different.

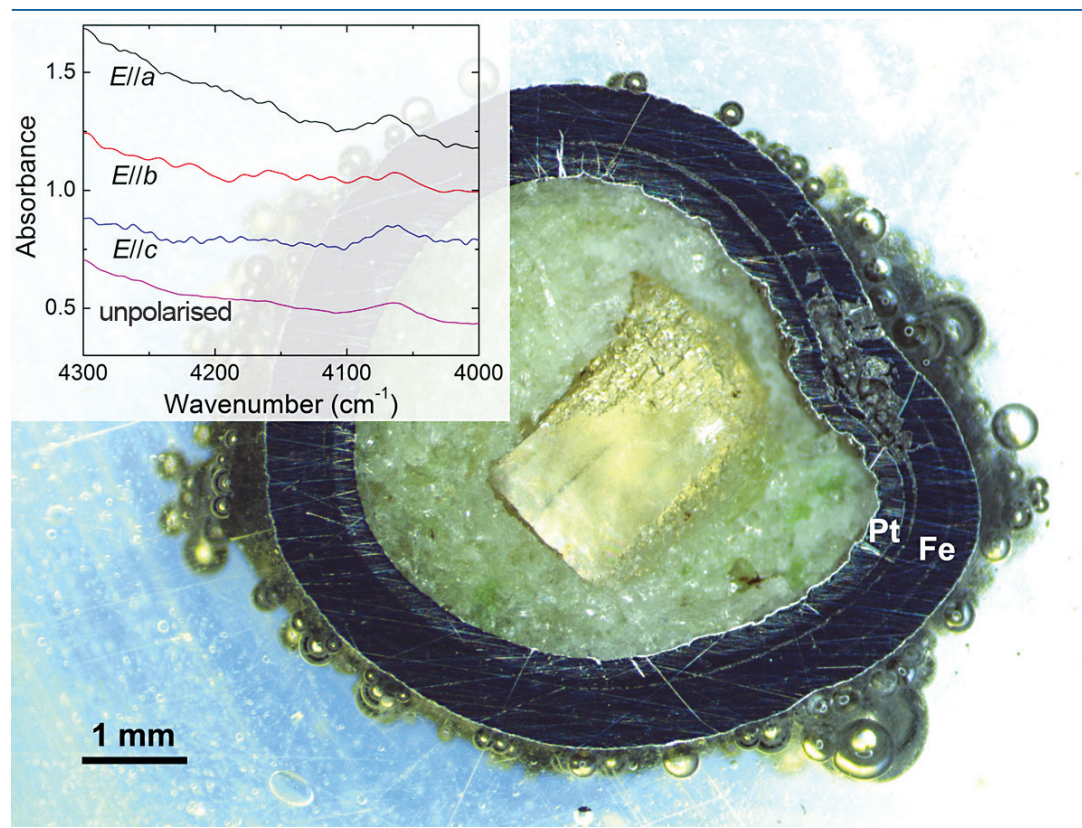
$\begin{array}{ll}\text { Figure } 1 & \text { Recovered orthopyroxene crystal annealed at } 2 \mathrm{GPa} \text { and } 1100^{\circ} \mathrm{C} \text { and polarised and } \\ \text { unpolarised FTIR spectra of the crystal containing molecular } \mathrm{H}_{2} \text {. The spectra were normalised }\end{array}$ to $1 \mathrm{~cm}$ thickness and vertically offset. The crystal was surrounded by fine powder of a spinel peridotite of broadly equilibrium composition (e.g., with similar composition between the crystal and orthopyroxene in the peridotite). The capsule was embedded in epoxy resin, and crystal remained nearly intact after the run. 


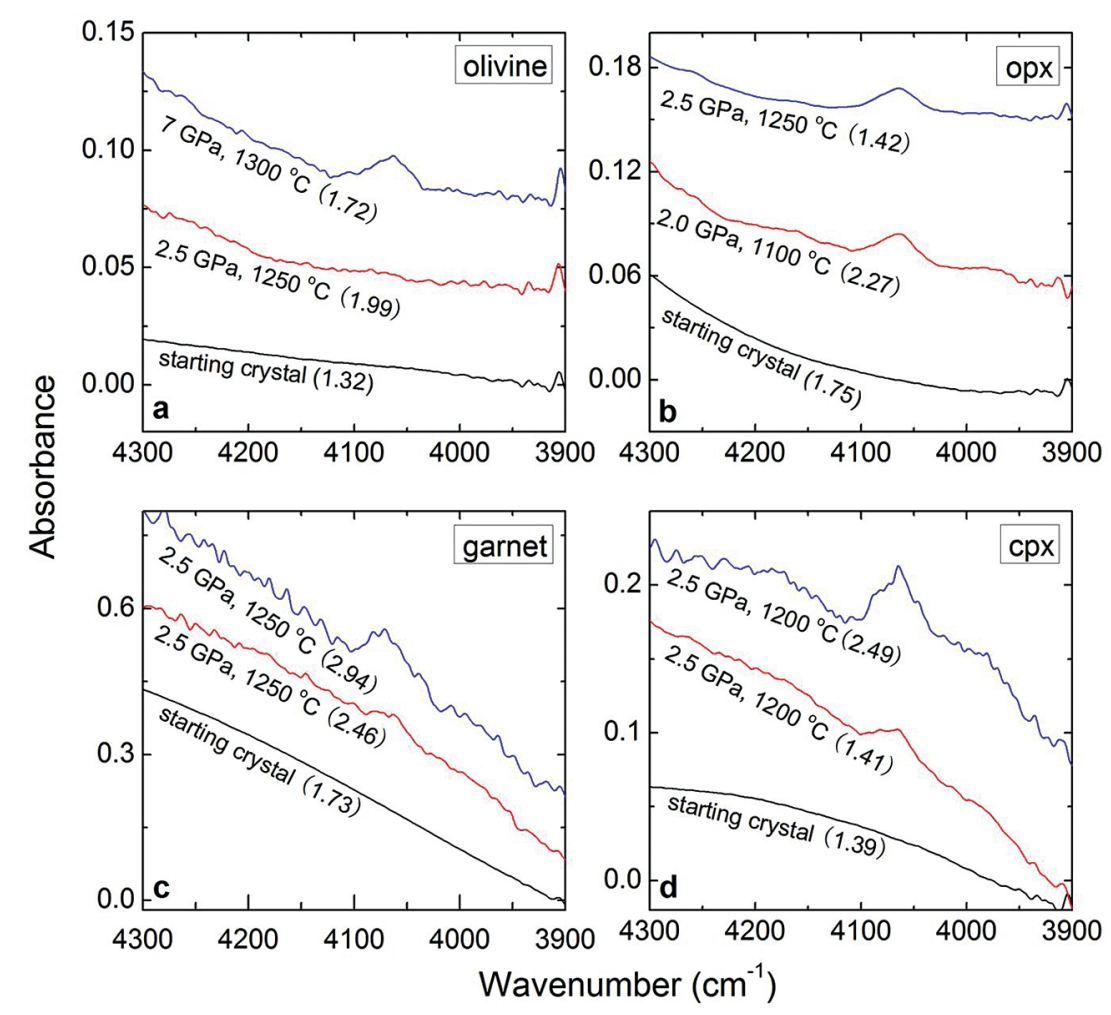

Figure 2 Unpolarised FTIR spectra of (a) olivine, (b) orthopyroxene, (c) garnet, and (d) clinopyroxene containing dissolved molecular $\mathrm{H}_{2}$ Experimental conditions are given below each spectrum; numbers in parentheses are the thickness $(\mathrm{mm})$ of the polished crystal. The spectra spectrum; numbers in parentheses are the thickness $(\mathrm{mm})$ of the polished crystal. The spectra were not normalised to constant thickness, but vertically offset. The two spectra for either after polishing to different thickness.

Additional evidence for an appreciable solubility of $\mathrm{H}_{2}$ in mantle minerals comes from two recent studies. At otherwise similar conditions (1.5 GPa and 1200 ${ }^{\circ} \mathrm{C}$ ), the $\mathrm{OH}$ solubility of olivine measured by FTIR is $\sim 50 \%$ lower for experiments buffered by Fe-FeO than by the more oxidising Ni-NiO buffer (Yang, 2016). This may reflect the higher water fugacity at $\mathrm{Ni}-\mathrm{NiO}$ buffer conditions, where the fluid consists of nearly pure water, while at the Fe-FeO buffer, the fluid consists of a mixture of $\mathrm{H}_{2} \mathrm{O}$ and $\mathrm{H}_{2}$ in comparable molar fractions (Yang, 2016). However, SIMS measurements that measure total $\mathrm{H}$ (i.e. $\mathrm{OH}+\mathrm{H}_{2}$ ) found only a reduction of bulk hydrogen contents of $\sim 5 \%$ in the $\mathrm{Fe}-\mathrm{FeO}$ as compared to the $\mathrm{Ni}-\mathrm{NiO}$ buffer runs (Gaetani et al., 2014). This would be consistent with a significant dissolution of $\mathrm{H}_{2}$ in the sample under reducing conditions, which nearly compensated for the decrease in $\mathrm{OH}$ content.

\section{Discussion}

The solubility of $\mathrm{H}_{2}$ measured in this study is about one order of magnitude lower than the water/OH solubility in minerals under comparable conditions (Keppler and Smyth, 2006). However, the observed solubility is not small on a planetary scale. While the measured contents are only $15-40$ ppm of $\mathrm{H}_{2} \mathrm{O}$ (Table 1), they will increase with pressure and hydrogen fugacity in the deeper mantle so that solubilities of hundreds of ppm should easily be achievable at higher pressures. $100 \mathrm{ppm}$ of $\mathrm{H}_{2} \mathrm{O}$ in the bulk mantle would already be equivalent to 0.3 ocean masses. The data in Table 1 suggest that the $\mathrm{H}_{2}$ solubility in minerals of very different structure and composition is quite similar. This is in line with the observation that the peak of $\mathrm{H}_{2}$ in the FTIR spectra is always at the same position, irrespective of structural details. Very likely, $\mathrm{H}_{2}$ does not substitute on a specific cation/anion site, but due to its small size, it fills interstitial positions. This would imply a broadly similar mechanism of $\mathrm{H}_{2}$ dissolution in all silicate minerals of the entire mantle.

Current models of the origin of water on Earth usually assume that hydrogen was contained in the chondritic material from which Earth accreted, with a possible contribution from icy objects that formed beyond the snow line in the outer solar system and were later scattered inward (Morbidelli et al., 2000; Marty and Yokochi, 2006; Rubie et al., 2011; Marty, 2012). Such models necessarily imply that planets formed close to the sun are relatively dry, compared to those formed at larger heliocentric distances. The observation of significant solubility of $\mathrm{H}_{2}$ in mantle minerals of this study suggests that some of the hydrogen on Earth could also have been sequestered directly from the solar nebula, in agreement with the recent discovery of a component with very low $\mathrm{D} / \mathrm{H}$ ratio in the deep mantle (Hallis et al., 2015). Hydrogen from a dense nebular atmosphere (Ikoma and Genda, 2006; Genda and Ikoma, 2008) could have first dissolved in the magma ocean (Hirschmann et al., 2012) and then have been trapped in the silicate minerals of the mantle (Fig. 3a). Such a mechanism would allow sequestration of hydrogen into a planet at any heliocentric distance, implying that planets close to the sun do not necessarily have to be poor in hydrogen.

Mantle plumes reaching down to the lowermost mantle are believed to be the source of ocean island basalts (McKenzie and O'Nions, 1995; French and Romanowicz, 2015). There is ample evidence showing that this deep mantle source is also a major reservoir of volatiles (Dixon et al., 2002; Saal et al., 2002), with hydrogen contents that are several times higher than in the MORB source of the upper mantle. This observation is, however, in striking contrast to experimental data, which show that $(\mathrm{Fe}, \mathrm{Mg}) \mathrm{O}$ ferropericlase and $(\mathrm{Mg}, \mathrm{Fe}) \mathrm{SiO}_{3}$ bridgmanite, the main minerals of the lower mantle, may dissolve at most a few ppm of $\mathrm{OH}$ in their structure (Bolfan-Casanova et al., 2000, 2002, 2003; Panero et al., 2015). The presence of some $\mathrm{H}_{2}$ in the lattice of these two minerals could easily reconcile these observations (Fig. 3b). Upon upwelling from the lower mantle, $\mathrm{fO}_{2}$ changes (Frost and McCammon, 2008), partially due to the phase change 


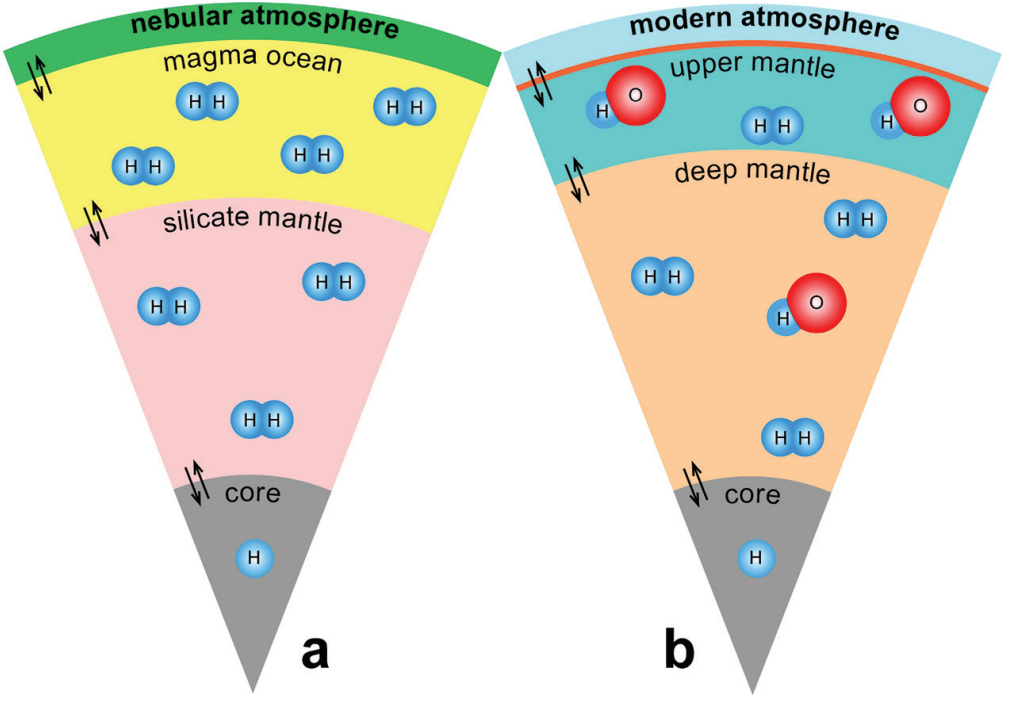

Figure 3 Schematic illustration of water storage (a) in the early mantle during the magma ocean stage and (b) in the modern mantle (not to scale). In the early Earth, where highly reducing conditions were prevailing, $\mathrm{H}_{2}$ might have been distributed between different reservoirs through equilibrium partitioning. In the modern Earth, where plate tectonics and mantle redox stratification are present, hydrogen in the oxidised shallow upper mantle is mostly dissolved in minerals as $\mathrm{OH}$ groups, while significant amounts of $\mathrm{H}_{2}$ are likely still present in the deep reduced mantle.

from bridgmanite, which stabilises $\mathrm{Fe}^{3+}$, to upper mantle minerals that mainly incorporate $\mathrm{Fe}^{2+}$. Accordingly, molecular $\mathrm{H}_{2}$ stored in the lower mantle may be converted to $\mathrm{H}_{2} \mathrm{O}$ or $\mathrm{OH}$ during the ascent of the mantle plume $\left(\mathrm{H}_{2}+\mathrm{Fe}_{2} \mathrm{O}_{3}=\right.$ $\mathrm{H}_{2} \mathrm{O}+2 \mathrm{FeO}$ ). It therefore appears that not only the deep cycle of carbon, but also the deep hydrogen cycle may be strongly coupled to the redox state of the mantle. Similar to carbon (Stagno et al., 2013), the oxidation of $\mathrm{H}_{2}$ to $\mathrm{H}_{2} \mathrm{O}$ could also trigger partial melting, since $\mathrm{H}_{2} \mathrm{O}$ is much more soluble in silicate melts than $\mathrm{H}_{2}$ (Hirschmann et al., 2012).

\section{Acknowledgements}

Comments by Fabrice Gaillard and one anonymous reviewer helped to improve the manuscript. This work was supported by grants to X.Y. from the National Basic Research Program of China (2014CB845904), the National Science Foundation of China (41590622 and 41372041), the Recruitment Program of Global Young Experts (China), and partly the Bayerisches Geoinstitut Visitors Program.

Editor: Bruce Watson

\section{Additional Information}

Supplementary Information accompanies this letter at www.geochemicalperspectivesletters.org/article1616

Reprints and permission information is available online at http://www. geochemicalperspectivesletters.org/copyright-and-permissions

Cite this letter as: Yang, X., Keppler, H., Li, Y. (2016) Molecular hydrogen in mantle minerals. Geochem. Persp. Let. 2, 160-168.

\section{References}

BELL, D.R., Rossman, G.R. (1992) Water in Earth's mantle: the role of nominally anhydrous minerals. Science 255, 1391-1397.

Bolfan-Casanova, N., KeppleR, H., Rubie, D.C. (2000) Water partitioning between nominally anhydrous minerals in the $\mathrm{MgO}-\mathrm{SiO}_{2}-\mathrm{H}_{2} \mathrm{O}$ system up to $24 \mathrm{GPa}$ : implications for the distribution of water in the Earth's mantle. Earth and Planetary Science Letters 182, 209-221.

Bolfan-Casanova, N., Mackwell, S., Keppler, H., McCammon, C., Rubie, D.C. (2002) Pressure dependence of $\mathrm{H}$ solubility in magnesiowüstite up to $25 \mathrm{GPa}$ : implications for the storage of water in the Earth's lower mantle. Geophysical Research Letters 29, 1029-1032.

Bolfan-Casanova, N., Keppler, H., Rubie, D.C. (2003) Water partitioning at $660 \mathrm{~km}$ depth and evidence for very low water solubility in magnesium silicate perovskite. Geophysical Research

DixOn, J.E., Leist, L., LANGMUIR, C.H., SCHILLING, J.G. (2002) Recycled dehydrated lithosphere observed in plume-influenced mid-ocean-ridge basalt. Nature 420, 385-389.

FrenCH, S.W., RomANOWICZ, B. (2015) Broad plumes rooted at the base of the Earth's mantle beneath major hotspots. Nature 525, 95-99.

Frost, D.J., MCCAMmON, C.A. (2008) The redox state of the Earth's mantle. Annual Review of Earth and Planetary Sciences 36, 389-420.

Gaetani, G.A., O’Leary, J.A., Koga, K.T., Hauri, E.H., Rose-Koga, E.F., Monteleone, B.D. (2014) Hydration of mantle olivine under variable water and oxygen fugacity conditions. Contributions to Mineralogy and Petrology 167, 968, doi: 910.1007/s00410-00014-00965-y.

GENDA, H., IKOMA, M. (2008) Origin of the ocean on the Earth: early evolution of water D/H in a hydrogen-rich atmosphere. Icarus 194, 42-52.

Hallis, L.J., Huss, G.R., Nagashima, K., Taylor, G.J., Halldórsson, S.A., Hilton, D.R., MottL, M.J., MeECH, K.J. (2015) Evidence for primordial water in Earth's deep mantle. Science 350, 795-797.

Hirschmann, M.M., Withers, A.C., ARdiA, P., Foley, N.T. (2012) Solubility of molecular hydrogen in silicate melts and consequences for volatile evolution of terrestrial planets. Earth and Planetary Science Letters 345-348, 38-48.

IKомA, M., GENDA, H. (2006) Constraints on the mass of a habitable planet with water of nebular origin. Astrophysical Journal 648, 696-706.

KeppLeR, H., SMYTH, J.R. (2006) Water in Nominally Anhydrous Minerals. Mineralogical Society of America, Washington DC., USA, 478 pp.

MARTY, B. (2012) The origins and concentrations of water, carbon, nitrogen and noble gases on Earth. Earth and Planetary Science Letters 313-314, 56-66. 
MARTY, B., YOKOCHI, R. (2006) Water in the Early Earth. Reviews in Mineralogy and Geochemistry 62, $421-450$. McKenZIE, D., O`NiOnS, R.K. (1995) The source regions of ocean island basalts. Journal of Petrology
36, 133-159.

Mierdel, K., Keppler, H., Smyth, J.R., Langenhorst, F. (2007) Water solubility in aluminous orthopyroxene and the origin of Earth's asthenosphere. Science 315, 364-368.

Morbidelli, A., Chambers, J., Lunine, J.I., Petit, J.M., Robert, F., Valsecchi, G.B., CYr, K.E. (2000) Source regions and timescales for the delivery of water to the Earth. Meteoritics \& Planetary Science 35, 1309-1320.

Panero, W.R., Pigott, J.S., Reaman, D.M., Kabbes, J.E., Liu, Z. (2015) Dry (Mg, $\mathrm{Fe}) \mathrm{SiO}_{3}$ perovskite in the Earth's lower mantle. Journal of Geophysical Research 120, 894-908.

Parman, S.W., Kurz, M.D., Hart, S.R., Grove, T.L. (2005) Helium solubility in olivine and implications for high ${ }^{3} \mathrm{He} /{ }^{4} \mathrm{He}$ in ocean island basalts. Nature 437, 1140-1143.

Regenauer-Lieb, K., Yuen, D.A., Branlund, J. (2001) The initiation of subduction: criticality by addition of water? Science 294, 578-580.

Rubie, D.C., Frost, D.J., Mann, U., Asahara, Y., Nimmo, F., Tsuno, K., Kegler, P., Holzheid, A., PALme, H. (2011) Heterogeneous accretion, composition and core-mantle differentiation of the Earth. Earth and Planetary Science Letters 301, 31-42.

SAal, A.E., Hauri, E.H., Langmuir, C.H., Perfit, M.R. (2002) Vapor undersaturation in primitive mid-ocean-ridge basalt and the volatile content of Earth's upper mantle. Nature 419, 451-455.

SCHMidT, B.C., HolTZ, F.M. (1998) Incorporation of $\mathrm{H}_{2}$ in vitreous silica, qualitative and quantita-
tive determination from Raman and infrared spectroscopy. Journal of Non-crystalline Solids 240, 91-103.

SHELBY, J.E. (1994) Protonic species in vitreous silica. Journal of Non-crystalline Solids 179, 137-147.

Stagno, V., OJWANG, D.O., MCCAMmon, C.A., Frost, D.J. (2013) The oxidation state of the mantle and the extraction of carbon from Earth's interior. Nature 493, 84-88.

WADHWA, M. (2008) Redox conditions on small bodies, the Moon and Mars. Reviews in Mineralogy and Geochemistry 68, 493-510.

YANG, X. (2016) Effect of oxygen fugacity on $\mathrm{OH}$ dissolution in olivine under peridotite-saturated conditions: an experimental study at $1.5-7 \mathrm{GPa}$ and $1100-1300^{\circ} \mathrm{C}$. Geochimica et Cosmochimica Acta 173, 319-336.

YANG, X., Gaillard, F., Scaillet, B. (2014) A relatively reduced Hadean continental crust and implications for the early atmosphere and crustal rheology. Earth and Planetary Science Letter
$393,210-219$ 